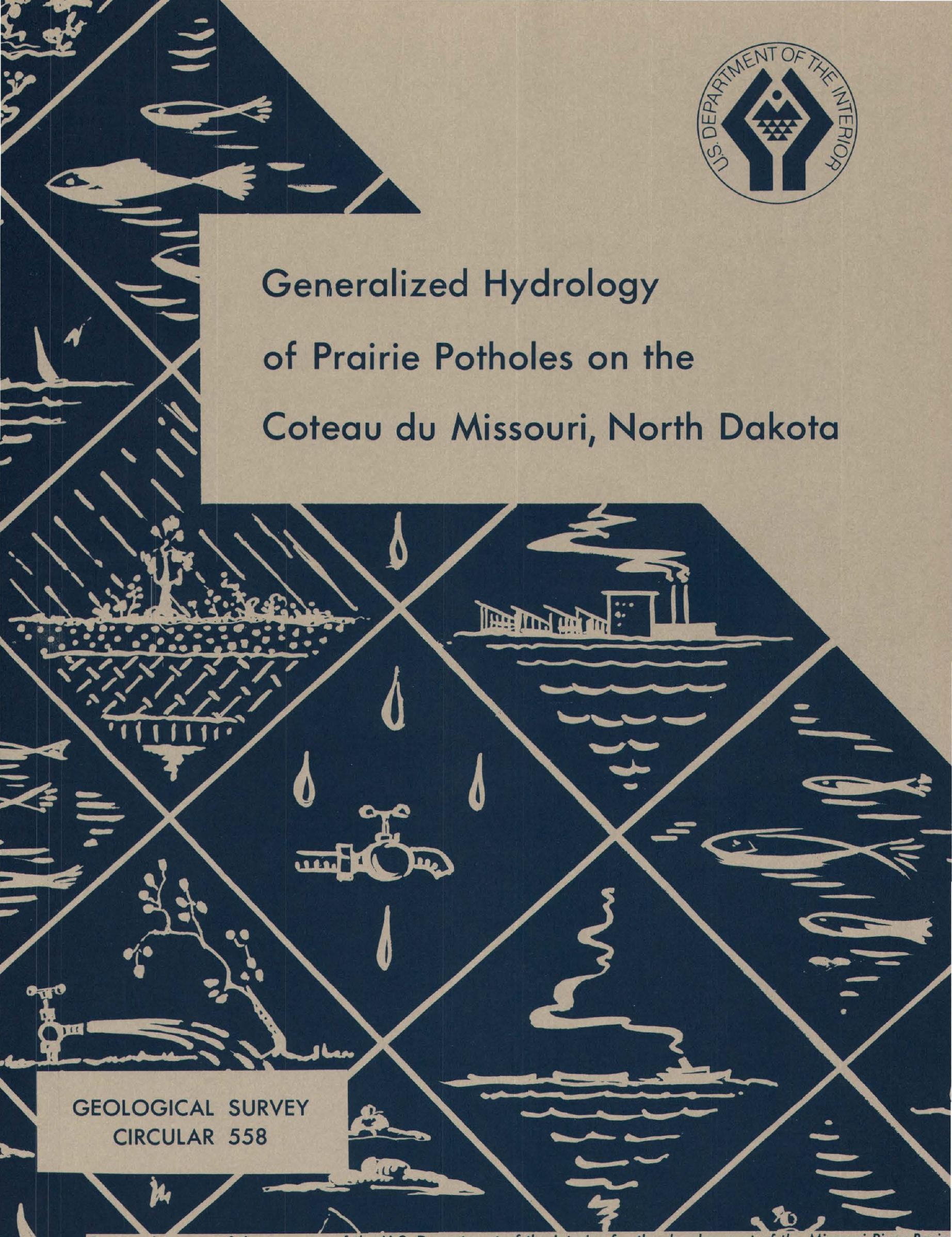





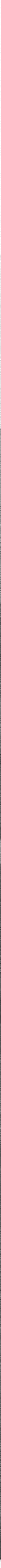

Aerial view of prairie potholes on the Coteau du Missouri. The water surfaces reflect the morning sun. Photograph by Wm. S. Eisenlohr, Jr., May 1967. 
Generalized Hydrology of Prairie Potholes on the Coteau du Missouri North Dakota 


\section{Generalized Hydrology}

of Prairie Potholes on the

\section{Coteau du Missouri, North Dakota}

By Wm. S. Eisenlohr, Jr., and Charles E. Sloan

GEOLOGICAL SURVEY CIRCULAR 558

Prepared as part of the program of the

U.S. Department of the Interior for the development of the Missouri River Basin and a contribution to the International

Hydrological Decade

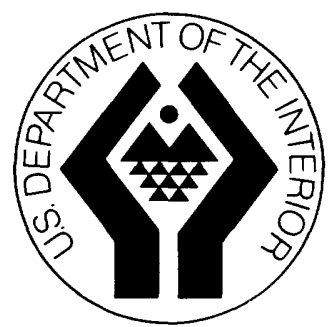


United States Department of the Interior STEWART L. UDALL, Secretary

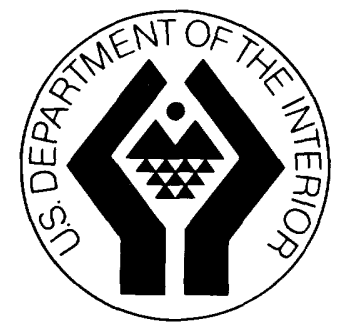

Geological Survey

William T. Pecora, Director<smiles>[V]</smiles> 


\section{CONTENTS}

Page

\section{1}

1

3

6
Page

Ground-water movement............. 6

Quality of water

Vegetation

References....................... 11

\section{ILLUSTRATIONS}

Page

Frontispiece. Aerial view of prairie potholes on the Coteau du Missouri.

Figure 1. Map of North Dakota showing the Coteau du Missouri, location of study areas, average annual precipitation, and average annual lake evaporation

2. Graphs showing relation of precipitation to basin inflow at an individual pothole .-

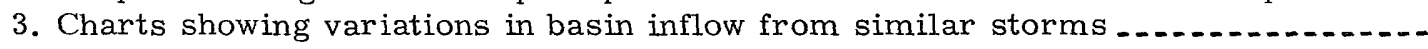

4. Photograph of a dense stand of cattail and bulrush in a pothole, September $1964 .-$ 



\title{
Generalized Hydrology of Prairie Potholes on the Coteau du Missouri, North Dakota
}

\author{
By Wm. S. Eisenlohr, Jr., and Charles E. Sloan
}

ABSTRACT

\begin{abstract}
This report presents all the information, obtained during the investigation, that lends itself to generalization. It describes conditions on that part of the Coteau du Missouri where there is little integration of drainage systems. The surface of the glacial drift in this region is dotted with shallow depressions known as prairie potholes that hold water for varying lengths of time. Precipitation directly on a pothole is the basic source of its water supply, but it is only about half the potential evaporation; therefore, potholes tend to go dry. Basin inflow from melting snow or rain occurs only when the soil is frozen or saturated, a condition so erratic in occurrence that seasonal or annual precipitation is of little value as an indication of basin inflow. Net seepage outflow occurs from potholes on the higher parts of the Coteau at very low rates, but it can amount to 20 to 30 percent of the total water loss from a pothole. Net seepage inflow occurs at the potholes on the lower parts of the Coteau.
\end{abstract}

The phreatic surface (water table) tends to be a subdued image of the topography and is generally very near the land surface. The water surfaces of the potholes are part of the phreatic surface, and therefore they can be used to prepare a contour map of the phreatic surface; wells usually act as piezometers and thus are useless for such a purpose.

Generally, potholes with water relatively low in dissolved solids have net seepage outflow, and those with water containing high concentration of dissolved solids have net seepage inflow. The direction of ground-water movement can therefore be inferred from the quality of water in potholes. The total salinity of water in a pothole is largely a function of the rate of ground-water flow and the relationship of seepage inflow to outflow.

The species of emergent aquatic vegetation that grow in a pothole are directly related to the permanence and salinity of the water at the particular site of each species. The report contains a table of the common species that can be used as indicators of these conditions.

\section{INTRODUCTION}

The hydrology of prairie potholes in North Dakota was investigated by the U.S. Geological Survey from 1959 to 1967 . Three study areas were used as shown in figure 1 . The evapotranspiration studies were made mostly in Ward and Dickey Counties and the groundwater studies were made mostly in Stutsman
County. This report presents all the information that can be generalized with some assurance that later work will not make major revisions necessary.

The Coteau du Missouri (fig. 1), as cefined by the U.S. Geographic Board (1933), is a "narrow plateau beginning in the northwest corner of North Dakota between Missouri River and River des Lacs and Souris River and running southeast and south, with its southern limit not well defined; and its western escarpment forming the bluffs on the Missouri." Many other definitions are in use; for the latest discussion of boundaries of this feature see Winters (1967). The present report is concerned with the eastern part of the area just defined where there is little or no integration of drainage systems. The Coteau is mantled with a layer of glacial drift that in places is several hundred feet thick; there are few outcrops of bedrock. The surface of the glacial drift is dotted with shallow depressions (see frontispiece) known as prairie potholes that hold water for varying lengths of time. There are more than 660,000 of them that contain water in the spring of a normal year (Schrader, 1955).

The ponds in these prairie potholes, and some associated larger bodies of water usually termed lakes, constitute the surface water supply of the Coteau. These ponds also make ideal breeding areas for migratory waterfowl.

Prairie potholes canbe classified in several ways by broad groups, but they also have individual characteristics that make strict classification difficult. Furthermore, some of the characteristics of prairie potholes change with changing hydrologic conditions, not only from year to year, but also within a year. The reasons for the individualistic and clanging 


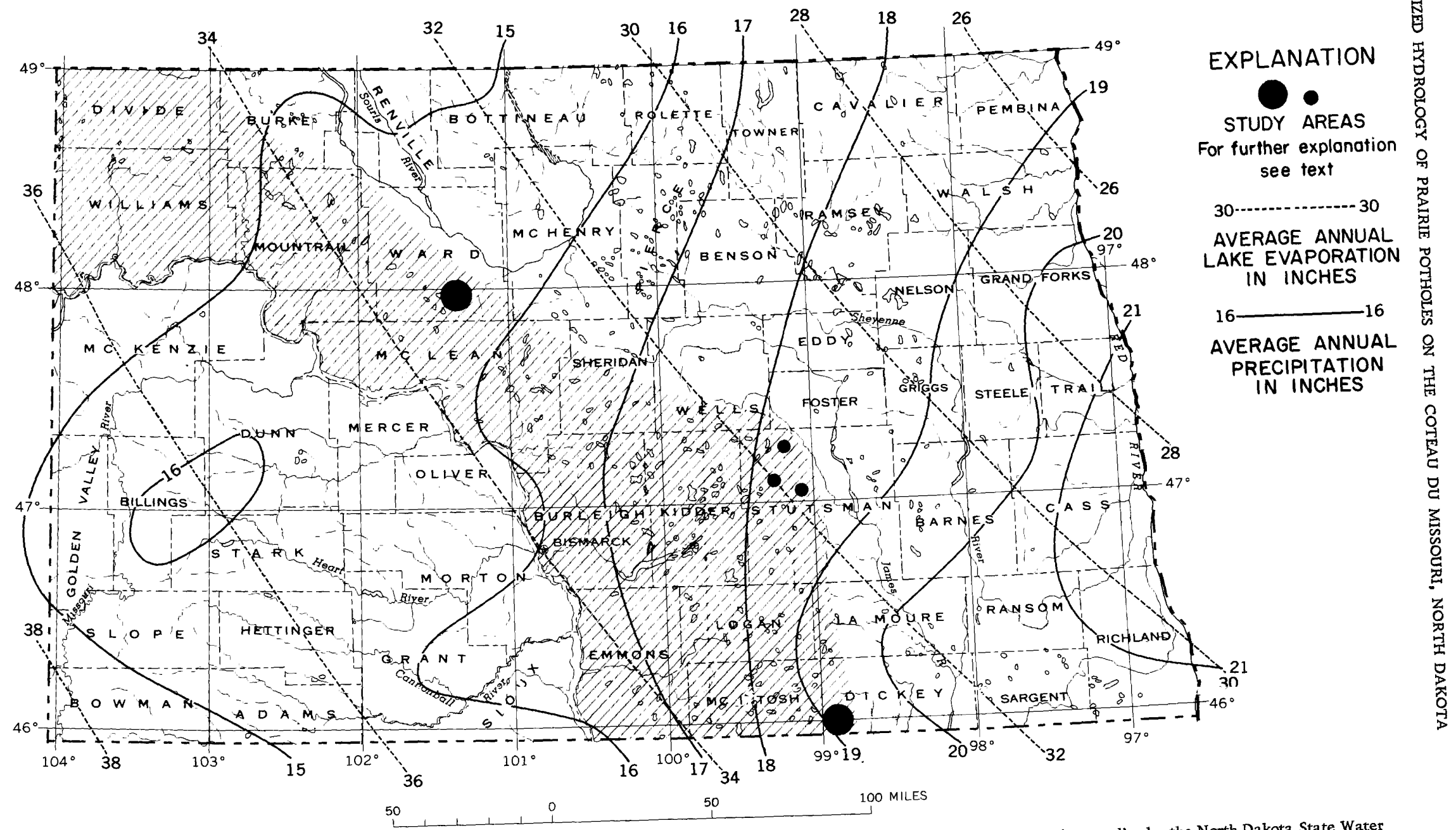

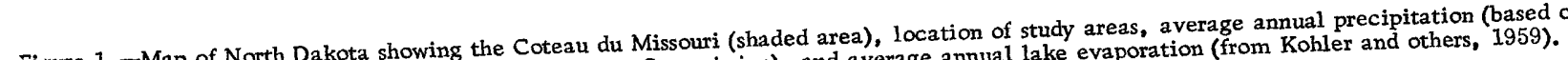


characteristics are usually found in the hydrologic, geologic, topographic, and botanic factors that make up the environment, either natural or as modified by man.

\section{WATER SUPPLY}

The sources of water in a pothole are precipitation on its surface, overland flow or runoff, and underground or seepage inflow; or as used in this paper, the sources are grouped into precipitation and basin inflow. Depletion of the water supply in a pothole is caused by evaporation (or evapotranspiration when vegetation is present), overflow, and seepage outflow. A detailed discussion of evapotranspiration losses has been published elsewhere (Eisenlohr, 1966b). Overflow is not a usual event, and when it does occur, it is mostly local and generally lasts for short periods.

Precipitation directly on a pothole is the basic source of water for a pothole; it is not influenced by the many factors that make basin inflow so erratic. Figure 1 shows that the ratio of annual precipitation to annual lake evaporation ranges from slightly less than a half in the western part of the State to somewhat more than a half in the eastern part. The range of this ratio between the study areas in Ward and Dickey Counties is less than the range for the entire State, but great enough that throughout the study, potholes in Ward County were generally drier than those in Dickey County. The fact that, by chance, the annual evaporation rate is about the same in Ward and Dickey Counties does not affect the conclusion. For a water body to be permanent in this region, basin inflow must be at least great enough to make up the difference between precipitation and all the water losses. That it is frequently insufficient for this purpose is shown by the tendency for potholes to become dry. In some years, however, it is more than adequate and a pothole will receive enough water for its pond to persist for several years. There is no regularity in such occurrences and no way of predicting them for a specific year.

Overland flow reaches a pothole only when the condition of the ground is such that water can flow over it without being absorbed; that is, the ground must be either frozen or saturated. Snowmelt flowing over frozen ground is believed by many people to be the largest source of water supply of prairie potholes. It does occur every year, but rarely is it as great as precipitation. Furthermore, basin inflows that are great enough to make up the water loss not offset by precipitation, occur about as frequently as a result of stummer rains as they do from snowmelt. Large basin inflows from snowmelt are generally restricted to those years when the snow cover remains until spring, as a result of persistent cold weather, and then melts rapidly while the ground is still frozen-a heavy snow cover is not essential. Such a condition occurred in Ward County in both 1960 and 1962, with the results for one pothole shown in figure 2 . During the preceding winters of both years there was less than normal seasonal snowfall. The basin inflow from the resulting snowmelt, however, amounted to more than preciritation plus its consequent basin inflow during the following summer, for the pothole shown in figure 2 .

Saturated soil has an effect similar to frozen soil in producing overland flow. Saturated soil in this sense refers to the inability of the top layers of the soil to absorb additional moisture, or to do so at a higher rate of absorbtion, and does not refer to any ccndition of the soil at depth. In a strict sense it is the infiltration capacity of the soil that is saturated rather than the soil itself. Saturated soils are the result of previous rains or intense rains. That such conditions are very erratic is shown in figure 2 where basin inflow, resulting from less than normal rainfall in the summers of 1961 and 1963, was greater than inflow from 60 percent above normal rainfall in 1962.

The general conclusion reached concerning the prairie potholes, and supported by figure 2 , is that seasonal or annual precipitaticn is of little value as a measure of water replenishment in a pond from basin inflow.

The importance of saturated soil in producing basin inflow is illustrated in the following examples. First, consider a pothole in Dickey County (pothole 5, fig. 3). This pothole received 0.18 foot of rain on July 5,1964 , and 0.05 foot about 24 hours later. There had been no previous rain since 0.07 foot fell on July 1 . Some drying of the soil undoubtedly took place in the 3-day interval, so that the effect of soil moisture on producing basin inflow on July 5 is not known. It is known that on July 5 the rainfall was very heavy, so heavy that it is not expected to occur at that rate and duration oftener than once in 10 years, on the average 


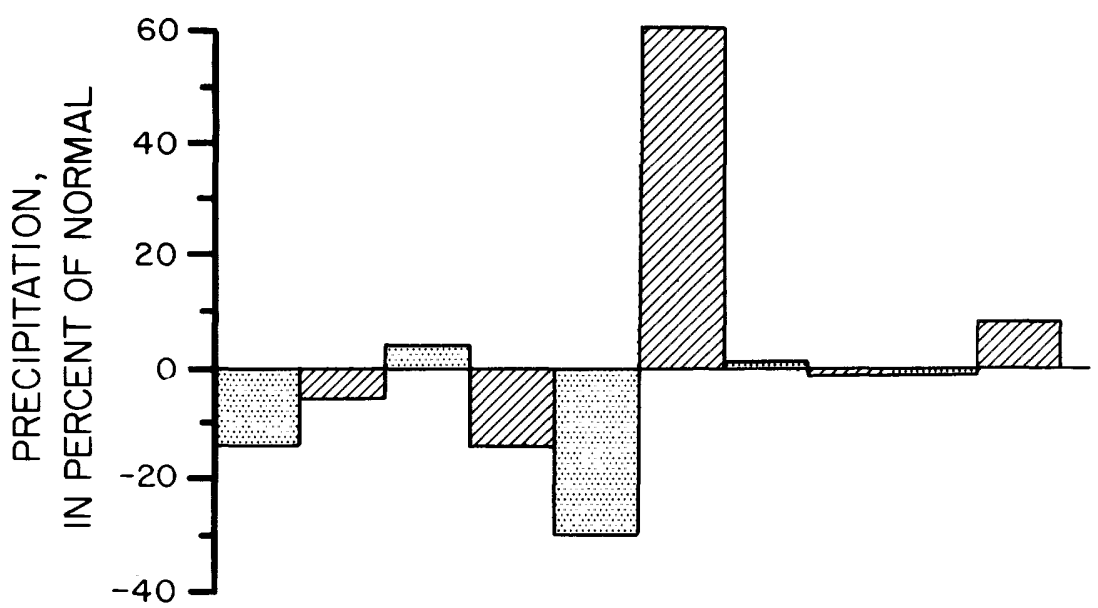

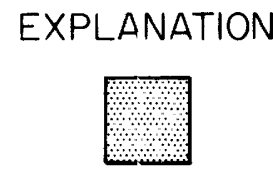

November - April

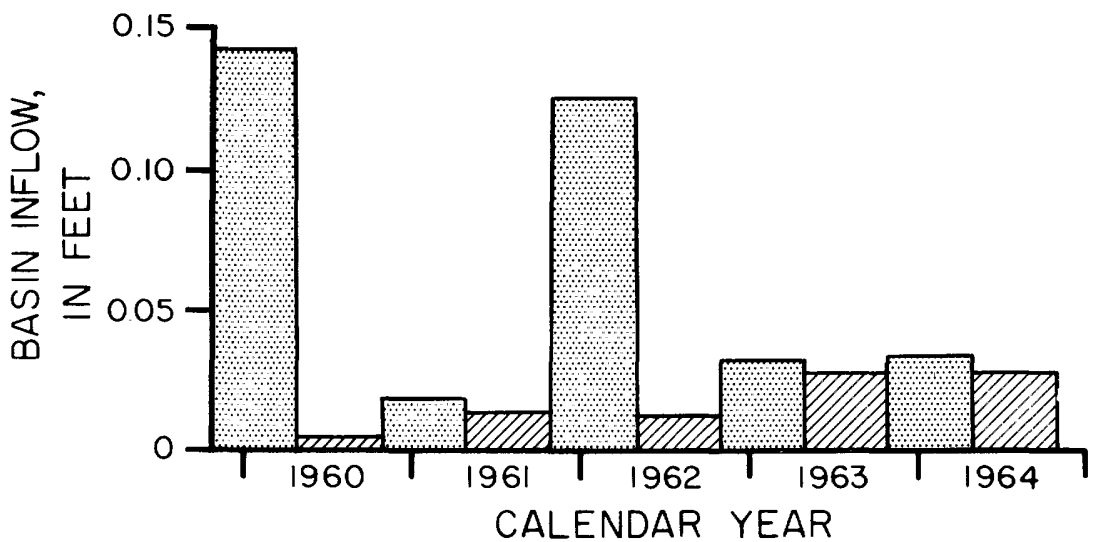

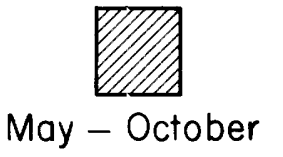

May - October

Figure 2.-Relation of precipitation to basin inflow at an individual pothole.

(U.S. Weather Bur., 1955). This storm raised the water level in the pond by 0.385 foot, 45 percent from precipitation and 55 percent from basin inflow. The second storm was not especially heavy, but coming so soon after a heavy rain, 0.05 foot of rain caused a rise of 0.156 foot in the pond on July 6 .

In contrast to these responses are those August 17-20, a little over a month later. There had been no rain for more than a week and less than 0.04 foot since the first of the month. There was 0.04 foot of rain in the morning of August 17, 0.06 foot in the afternoon, and 0.05 foot about noon of August 20 . There was no basin inflow from any of these rains, and the first rain of 0.04 foot fell in about half an hour.

We thus have two storms that produced 0.05 foot of rain each; one that produced basin inflow on July 6 equal to twice the amount of rain that fell directly on the pond, and a second on August 20 that produced no basin inflow at all. It is interesting to note also that the 0.05 foot of rain that fell about midnight July 5 was far more effective in producing basin inflow than the 0.18 foot of rain that fell less than 24 hours previously.

The lower part of figure 3 shows a second example (pothole 1), but the time relationship is reversed and rainfall intensity probably had no effect. The chart for June 13-14, 1965, shows that rain of 0.12 foot produced a rise of 0.146 foot in the pond, 0.021 foot of which was basin inflow or less than 0.2 of the amount of direct precipitation. There had been no rain for more than 2 weeks prior to the rain on June 13. The chart for July 20-23 shows that a rain of 0.11 foot on July 22-23 caused the pond to rise 0.495 foot, 0.387 foot of which was basin inflow or 3.6 times the amount of direct precipitation on the pond. The difference is seen as the effects of the rain of 0.05 foot on 
July 20 , only 42 hours before the rain on July 22.

Potholes that have very large drainage areas may have areas that are noncontributing except in years of high basin inflow. In those years, however, the normally noncontributing areas may overflow into the pothole and add enough water to assure a water supply in the pothole for several years.

This condition is believed to be the explanation of a sequence of events that occurred in Ward County. There, a pothole went dry in 1964, 3 years after other potholes around it went dry. When the other potholes received an appreciable amount of water in 1965 and 1966, the subject pothole, although it has by far the largest drainage area, received little water, presumably because much of the drainage area did not contribute in those yeers.

Seasonal evaporation (May-October) from potholes clear of emergent aquatic vegetation was found to be very close to the values given by Kohler, Nordenson, and Baker (1959) for lake evaporation. Kohler shows seasonel evaporation to average about 84 percent of annual evaporation from lakes in North Dakota (fig. 1).

Seasonal evapotranspiration from potholes with vegetation averaged about 10 percent less than seasonal evaporation from equivalent potholes clear of vegetation. There is, of course, a great variation in transpiration during the season as the vegetation grows, reaches maturity, and then becomes dormant or dies. Evaporation is directly related to the

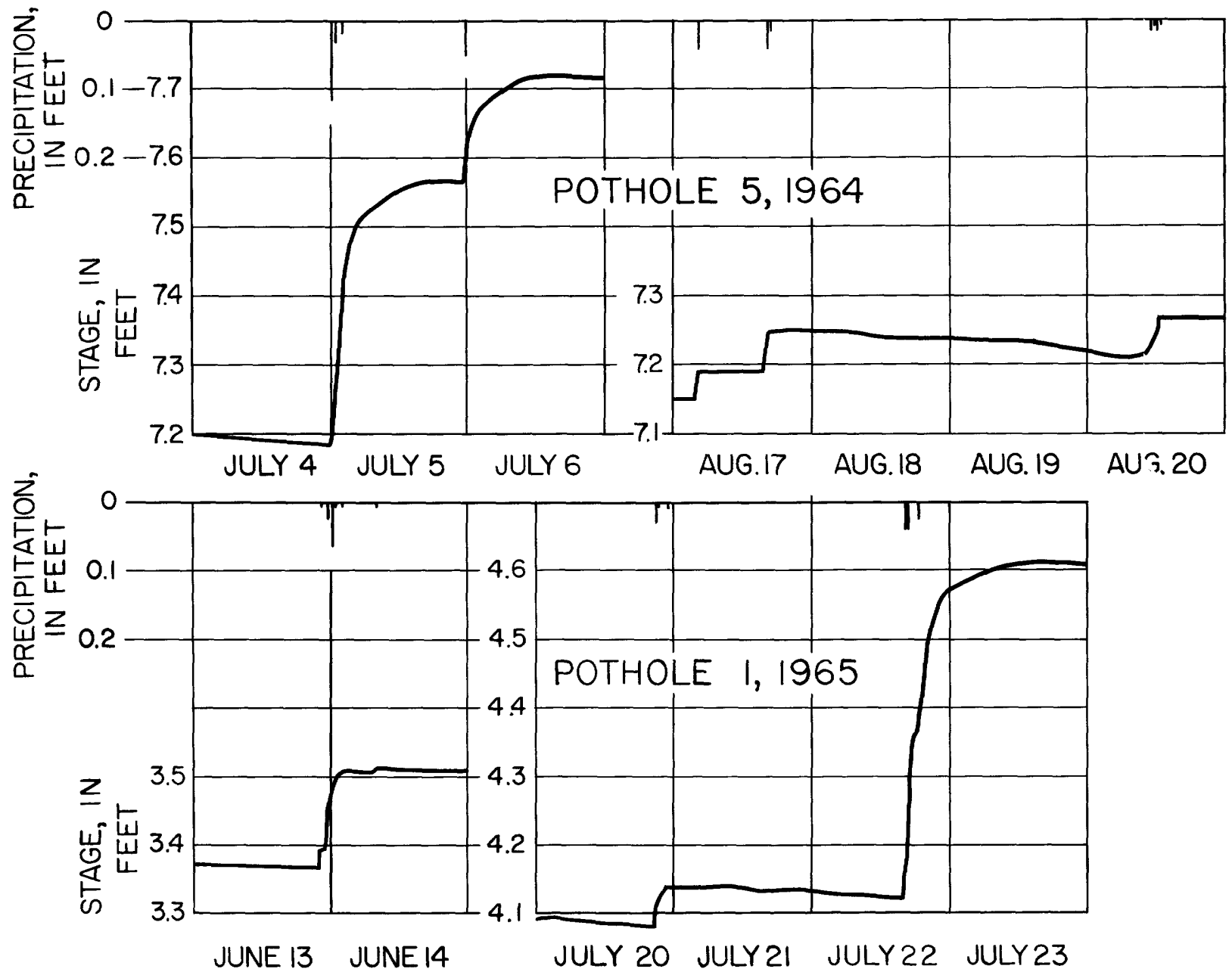

Figure 3. - Charts showing variations in basin inflow from similar storms. 
rate at which water vapor is removed from the vicinity of the evaporating surface by air currents or wind. In a pothole filled with vegetation, there is practically no wind, most of the time, at the water surface. Therefore, evaporation rates are very low. They are so low that even with high rates of transpiration that occur in midsummer the total evapotranspiration for a season is less than that of a pothole clear of vegetation in a comparable situation.

Seepage rates were computed only for till terranes. It had been expected that seepage in till would be negligible. Net seepage outflow occurred in all potholes where seepage was computed. The rates were very low, seldom exceeding 0.01 foot of water per square foot of pond area per day and frequently being less than half that rate. However, these are not negligible rates because they often represent 20 to 30 percent of the total loss of water from a pothole.

Seepage outflow rates computed for the vegetated potholes were much greater than those for the potholes clear of vegetation. They were so much greater that the total water loss was on the order of 10 percent higher from the potholes with vegetation than from those without.

Much of the outflow seepage from potholes in highland areas may return to the surface in lower areas, as ground-water discharge, where it can evaporate. As the evaporation potential is so much greater than precipitation, it is probable that evapotranspiration dissipates most of the precipitation that falls in the prairie pothole region.

Net seepage inflow to potholes probably occurs only in lowland areas where there is a potential for ground-water discharge. No measurements were made of such flows, but springs and other evidence of ground-water discharge were observed in many parts of such areas.

\section{GEOLOGY}

The Coteau du Missouri was an extensive area of glacial stagnation during several advances of the Late Wisconsin Glacier, and it is largely covered by deposits of glacial till and outwash.

The areas of till on the Coteau are characterized by a hummocky knob-and-kettle topography, abounding in prairie potholes and lacking an integrated drainage pattern. The till was deposited directly from the glacial ice with little modification by running water. That is, there is little stratification within the till. It consists of a heterogeneous, unsorted mixture of clay, silt, sand, pebbles, cobbles, and boulders that is poorly permeable. Cracks and joints that have developed through weathering processes have increased the permeability of the till in the surficial unsaturated zone. In addition, permeable deposits of sand and gravel are locally enclcsed by poorly permeable till in many places.

Outwash sediments were deposited by meltwater from the glacier and consist largely of permeable sand and gravel. Areas of outwash have a less irregular topography than the till terrane and generally contain larger and more widely scattered lakes.

\section{GROUND-WATER MOVEMENT}

The movement of ground water on the Coteau is related to the surface topography and the permeability of the underlying earth materials. The top of the zono of saturation, where the pressure is atmospheric, is called the phreatic surface or water table. The term "phreatic surface" has been chosen for this feature in order to avoid ideas usually associated with water table, sucl as those of a planar surface or of not occurring in poorly permeable materials.

The phreatic surface tends to be a subdued image of the topography and is generally very near the land surface. Beneath the phreatic surface, water moves by gravity from areas of higher fluid potential toward areas of lower fluid potential.

The highest fluid potentials are found under the highland areas of the Coteau where flow will be generally downward. Although groundwater movement in the Coteau is generally downward, there is some lateral and even upward movement, as shown by the local discharge into many of the potholes.

Because much of the glacial till on the Coteau is at relatively high elevations, potholes in till generally lose water through seepage outflow. Conversely, because much of the outwash on the Coteau is at relatively low elevations, many of the potholes and lakes in outwash gain water through seepage inflow.

A well that has been dug or drilled below the phreatic surface, and cased for most of its 
length, will act as a piezometer. That is, the water level in the well will represent the average head or fluid potenital in the uncased part of the well. Because the change in head with depth can be substantial, water levels in wells cannot be used to map the phreatic surface. However, as the water levels in potholes are part of the phreatic surface (with few exceptions), they can be used to prepare a contour map of the phreatic surface.

In areas underlain by poorly permeable till, the phreatic surface may be steeply inclined, but there is little evidence to suggest appreciable lateral movement of water in the direction of the inclination; the dominant direction of ground-water flow appears to be vertical. Several lines of evidence suggest vertical movement in till: (1) Large difference in water levels in closely spaced observation wells that have been cased to different depths, (2) large and rapid water level changes in observation wells, (3) relative independence of water levels in potholes and adjacent wells, and (4) the ofttimes steep configuration of the phreatic surface.

The water levels in shallow observation wells in till rise several feet every spring at a time when recharge is far too small to account for it. Declines in water levels in nearby potholes have been observed during parts of the period in which the water levels in wells are rising. The reason is probably the rapid return to the phreatic zone, during the spring thaw, of water that had migrated as water vapor slowly upward to the frost zone during the previous winter (Willis and others, 1964).

In areas of outwash, there is substantial lateral movement of ground water. Springs and seeps are numerous. Commonly this groundwater discharge is fresh to slightly saline. Many of the springs are artesian, and, in some of the saline lakes, they are sites for the growth of fresh-water vegetation. Spring inflow in a few potholes is great enough to maintain permanent water bodies.

There are many potholes that go dry every year, either because they do not get enough inflow, or because outflow seepage is too great, or a combination of the two. Potholes that have very high rates of outflow seepage in till terranes are usually underlain in part by permeable sand deposits.

\section{QUALITY OF WATER}

All natural waters contain some dissolved solids. The concentration of these dissolved solids affects the usefulness of a water supply. Normally, the chief interest in a water supply is in relation to direct human use. In tre pothole region, however, the major interest in the salinity of water is its use by migratory waterfowl. R. E. Stewart has chosen a slightly different classification than that used by the U.S. Geological Survey as being more appropriate for waterfowl applications, and his classification has been adopted for this report. (See table under the section "Vegetation.")

The salinity of water is usually expressed as the number of milligrams of solic's dissolved in a liter of solution. An approximation of the number of milligrams per liter of dissolved solids can be obtained quickly and easily by measuring the specific electrical conductance of a sample. If the conductance is expressed in micromhos per square centimeter per centimeter at $25^{\circ} \mathrm{C}$ (frequently written micromhos per centimeter), the number is close to the number of milligrams per liter of dissolved solids in prairie pothole waters. There is a difference between the two, and the difference for fresh water and for brine is very significant for most purposes, the number of milligrams per liter ranging from 0.7 times the number of micromhos per centimeter for fresh water to more than 1.2 times the number for brines. For the broad classifications used in this report, however, it is practical to ignore the difference.

The salinity of water varies from pond to pond and over the Coteau covers most of the range of salinity found in nature, from very fresh water, less than 100 micromhos per centimeter, to brines of more than 70,000 micromhos per centimeter, or double the concentration of sea water. The salinity of water found in any particular pond is frequently a good indicator of whether the pothole is in a region of ground-water recharge or discharge, as explained later.

As it was stated previously, the evaporation potential is much greater than the precipitation. Therefore, for the region as a wrole, it would be possible to remove by evaporation (and transpiration) all the water supplied to 
the region if that water were uniformly available for evaporation. Water evaporated from a pothole leaves behind the solids that it dissolved on its way to the pothole. If there is no mechanism available for removing these solids, then they will continue to accumulate.

Wind has been observed as an agent for removing saline deposits from potholes and lakes. It is questionable, however, whether this has any large effect on the salinity of water. If wind were truly an effective force in removing salts from potholes that go dry, not so many potholes that go dry would remain consistently saline.

Seepage outflow removes dissolved solids from potholes. All the dissolved solids will be removed from a pothole if the pond goes dry before the water reaches such concentrations that parts of some dissolved constituents are precipitated and remain on the bottom of the pothole or within the shallow sediments covering the bottom.

In contrast, if there is no seepage outflow, either because the bottom of the pothole is watertight (which probably never occurs) or because over the entire bottom there is a ground-water potential for seepage inflow, then there is no mechanism for removal of dissolved solids and their concentration can be expected to increase. The total salinity of water in such a pothole is largely a function of the rate of seepage inflow and the salinity of the inflowing water.

Surface inflow can be very irregular. During periods of great inflow to potholes, some of them overflow and produce inflow to the pothole next downstream, which may increase or decrease the concentration of solids there. Few observations have been made to evaluate this effect, which is illustrated by the following example. There is a small pond within 50 feet of a larger one whose water level is at least 3 feet higher. Both ponds are in till. The higher, larger pond did not overflow into the lower one (during the study) until 1964. How long it had been since the previous overflow is not known. In 1962 the concentration of dissolved solids in the lower pond was less than 20 percent of that in the upper one. After the overflow occurred, the concentrations were about the same. The lower pond has a very small drainage basin and, before the overflow, it usually went dry by the middle of the summer. Presumably, since the last overflow prior to 1962, precipitation anc outflow seepage had diluted and removed most of the dissolved solids brought in by that overflow. This indicates also that there is little lateral movement of ground water between the two.

According to the foregoing cliscussion, potholes in highland areas, where seepage outflow generally prevails, could be expected to, and do, contain mostly fresh or slichtly saline water. Likewise, potholes in lowland areas, where seepage inflow generally prevails, could be expected to, and do, contain water much more saline than in the highland areas. This statement is about water in the potholes, but as stated in the section on "Grourd-water movement," numerous springs in the glacial outwash provide good water in lowland areas.

\section{VEGETATION}

Many potholes contain emergent aquatic vegetation (fig. 4). This vegetation exerts a significant effect on water losses. It is also a good indicator of the quality of water in which it grows and of the length of time it is inundated.

The presence of emergent aquatic vegetation affects the water loss to the air in two ways. It reduces evaporation br reducing wind at the water surface and it ac'ds to the water loss through the transpiration process (Eisenlohr, 1966a). The effects vary throughout the year, but the total effect on an annual basis is that evapotranspiration from a pothole filled with emergent aquatic vegetation is somewhat less than evaporation from a pothole clear of vegetation, perhaps by 10 percent or more.

The reduction in water loss to the air in potholes with vegetation, compared with those without, seems to be more than offset by substantially greater loss by seepage. The reason for this greater seepage is not known. There is no evidence to indicate whether the increase is cause or effect. One might theorize that vegetation only grows in soils permeable enough to allow the greater seepage and another might theorize trat products of decaying vegetation may aggregate the finer particles underlying the pothcle and thereby increase soil permeability and reduce the resistance to flow below the pond.

The species of vegetation that grow in a pothole are directly related to the permanence and salinity of the water at the particular site 


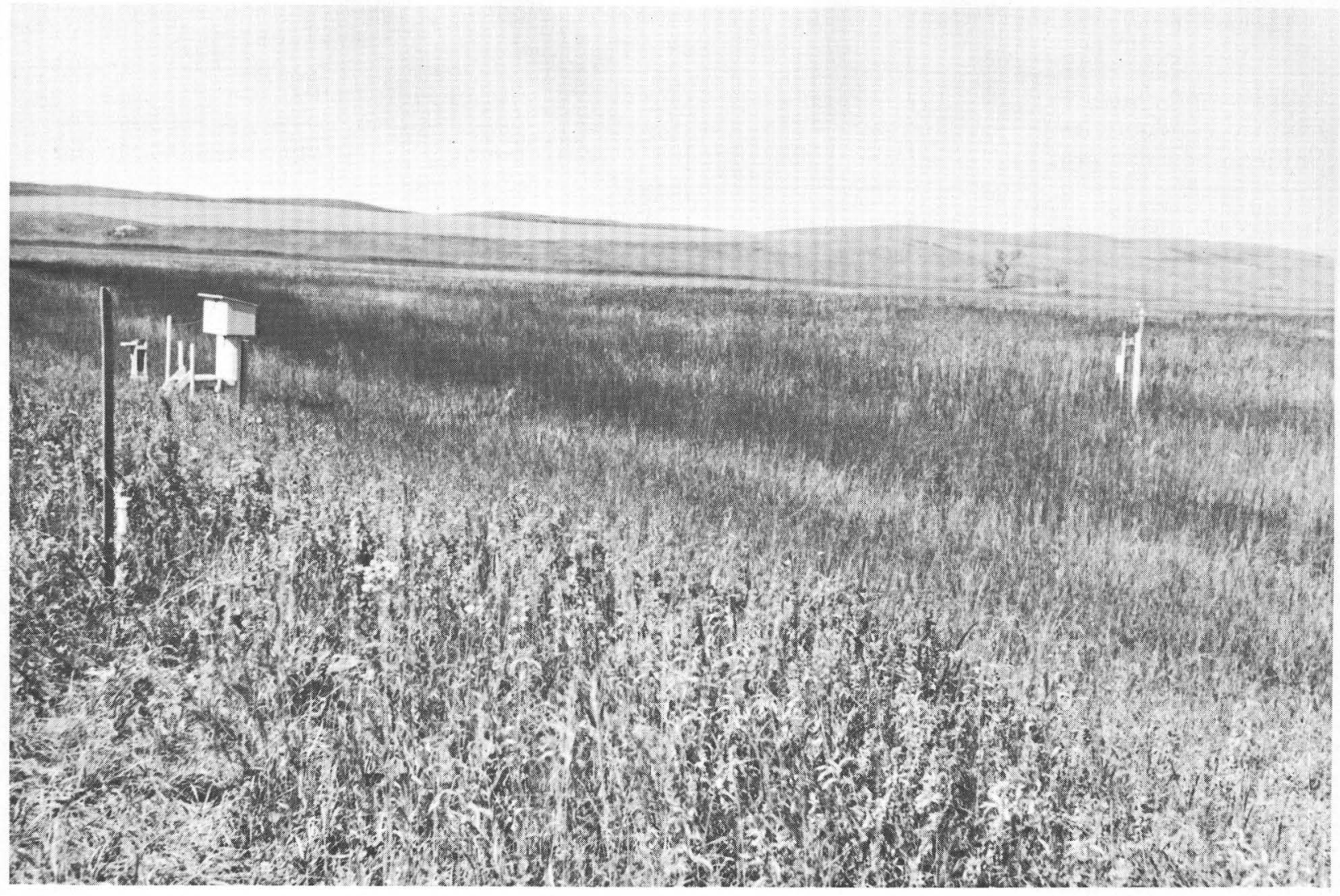

Figure 4.-Dense stand of cattail and bulrush in a pothole, September 1964. As a result of the high water levels in 1964 and 1965, this pothole was clear of vegetation in 1965.

of each species. The term "permanence" is used extensively in the classification of prairie potholes to indicate the extent to which a pothole water body is permanent. As used in connection with vegetation, it indicates the period of time, usually within a year, that the ground on which the vegetation grows is submerged or inundated. As this permanence and salinity are continually subject to change, so also are the species and densities of vegeta- tion continually subject to change, but less rapidly. The way these factors affect emergent vegetation is indicated in the accompanying table prepared by R. E. Stewart on the basis of hundreds of observations extending over several field seasons. The table lists only those species that were found in enough potholes to be classed as commonly present. For a more detailed table see Stewart and Kantrud (1968).

Common species of emergent vegetation as indicators of permanence and salinity of water in potholes on the Coteau du Missouri, N. Dak.

[Prepared by R. E. Stewart, Bureau of Sport Fisheries and Wildlife]

\begin{tabular}{|c|c|c|c|}
\hline \multirow{2}{*}{$\begin{array}{l}\text { Salinity and range in } \\
\text { specific conductance }{ }^{1} \\
(\text { micromhos per } \mathrm{cm} \text { ) }\end{array}$} & \multicolumn{3}{|c|}{ Permanence of water at site of indicated species ${ }^{2}$} \\
\hline & Less than 1 month & $1-4$ months & More than 4 months \\
\hline $\begin{array}{l}\text { Fresh } \\
0-700\end{array}$ & $\begin{array}{l}\text { Poa palustris } \\
\text { Calamagrostis canadensis } \\
\text { Carex praegracilis } \\
\text { Carex lanuginosa } \\
\text { Juncus dudleyi }\end{array}$ & $\begin{array}{l}\text { Alisma triviale } \\
\text { Polygonumi coccineum } \\
\text { Glyceria grandis } \\
\text { Carex atherodes } \\
\text { Sparganium eurycarpum }\end{array}$ & $\begin{array}{l}\text { Scirpus heterochaetus } \\
\text { Scirpus fluviatilis } \\
\text { Typha latifolia }\end{array}$ \\
\hline
\end{tabular}


Common species of emergent vegetation as indicators of permanence and salinity of water in potholes on the Coteau du Missouri, N. Dak.-Continued

\begin{tabular}{|c|c|c|c|}
\hline \multirow{2}{*}{$\begin{array}{l}\text { Salinity and range in } \\
\text { specific conductance } \\
\text { (micromhos per } \mathrm{cm} \text { ) }\end{array}$} & \multicolumn{3}{|c|}{ Permanence of water at site of indicated species ${ }^{2}$} \\
\hline & Less than 1 month & $1-4$ months & More than 4 months \\
\hline $\begin{array}{l}\text { Slightly saline } \\
700-3,000\end{array}$ & $\begin{array}{l}\text { Calamagrostis inexpansa } \\
\text { Juncus balticus } \\
\text { Juncus torreyi } \\
\text { Spartina pectinata } \\
\text { Hordeum jubatum } \\
\text { Carex sartwellii }\end{array}$ & $\begin{array}{l}\text { Alisma gramineum } \\
\text { Beckmannia syzigachne } \\
\text { Scolochloa festucacea } \\
\text { Carex atherodes } \\
\text { Eleocharis palustris }\end{array}$ & $\begin{array}{l}\text { "Typha glauca"3 } \\
\text { Scirpus acutus }\end{array}$ \\
\hline $\begin{array}{l}\text { Moderately saline } \\
3,000-12,000\end{array}$ & $\begin{array}{l}\text { Hordeum jubatum } \\
\text { Distichlis stricta } \\
\text { Muhlenbergia asperifolia } \\
\text { Spartina gracilis }\end{array}$ & $\begin{array}{l}\text { Eleocharis palustris } \\
\text { Scirpus americanus } \\
\text { Puccinellia nuttalliana }\end{array}$ & $\begin{array}{l}\text { Scirpus acutus } \\
\text { Scirpus paludosus }\end{array}$ \\
\hline $\begin{array}{l}\text { Very saline or briny } \\
12,000-70,000\end{array}$ & $\begin{array}{l}\text { Distichlis stricta } \\
\text { Muhlenbergia asperifolia }\end{array}$ & $\begin{array}{l}\text { Salicornia rubra } \\
\text { Puccinellia nuttalliana } \\
\text { Suaeda depressa } \\
\text { Scirpus nevadensis }\end{array}$ & Scirpus paludosus \\
\hline
\end{tabular}

${ }^{1}$ These ranges in specific conductance differ somewhat from those used by the Geological Survey which are based on other needs, especially that of defining fresh water for domestic use.

2The time divisions used here are purely arbitrary; large deviations from them can be expected.

${ }^{3}$ Recent investigations show this species to be a hybrid of T. latifolia and T. angustifolia.

There are no common names for many of the species listed; therefore, it is necessary to consult a manual of plants to make full use of the above table. For the casual reader some common names of the genera listed are, alphabetically:

Alisma, waterplantain

Beckmannia, sloughgrass

Calamagrostis, reedgrass

Carex, sedge

Distichlis, saltgrass

Eleocharis, spikerush

Glyceria, mannagrass

Hordeum, wild barley

Juncus, rush

Muhlenbergia, muhly

Poa, meadowgrass

Polygonum, smartweed

Puccinellia, alkaligrass

Salicornia, glasswort, samphire

Scirpus, bulrush

Scolochloa, sprangletop, whitetop

Sparganium, burreed

Spartina, cordgrass

Suaeda, sea blite

Typha, cattail

The table is very useful in making a first approximation of the salinity of any particular pothole. Vegetation in any pothole usually is composed of several species. Each species seems to be associated with a range of salinity and permanence of water to such an extent that it can be used as an indicator of those conditions in this area. Where species of different ranges in salinity are growing together, the salinity indicated is the range common to both species. For example, a pothole may concontain both Carex atherodes and Eleocharis palustris. As shown in the table, Carex atherodes grows in fresh to slightly saline water and Eleocharis palustris grows in slightly saline to moderately saline water. This would indicate that the pothole has slightly saline water.

As the water level in a pothole fluctuates it covers and uncovers vegetation on its shores. Therefore, vegetation that grows in the center of a shallow pothole can also grow near the shore of a deep pothole where the permanence of water is about the same. In using the table to estimate the permanence of water, the user should be careful to apply it only to the site of the particular plant species observed.

Stewart's table may be incomplete because it does not include a permanence beyond which no vegetation, or only a very few well adapted species, will survive. Such a condition is 
described by Harris and Marshall (1963) who also cited many references to the effect that continuously flooded emergent vegetation seldom survives for more than 5 years, or less if subjected to increased wave action or greater depth of flooding. With respect to their own investigation (p. 342) they reported:

"Spike rush [Eleocharis palustris] and soft-stem bulrush [Scirpus validus] were destroyed by flooding with over 15 inches of water in 3 years and in any continuously flooded area in 4-5 years. These species persisted only in shoreline evaporation zones. Common cattail [Typha latifolia] and sedges [Carex atherodes, C. pseudocyperus, and C. lacustris] were gone from continuously flooded areas in $4-5$ years and also persisted only in shoreline evaporation zones. 'Hybrid' cattail remained unchanged in 24 inches of water throughout 5 years of flooding."

Whether such a situation exists for the common species of the open prairie on the Coteau du Missouri is uncertain. No specific observations were made for this purpose. It was definitely observed, however, that permanence and depth of water have a controlling effect on emergent vegetation. Such vegetation disappears rapidly once it is inundated beyond the critical depth.

Once emergent vegetation has died as a result of flooding, rapid regrowth will not take place until the soil is again uncovered. As stated by Kadlec (1962), "many emergent plants, including cattail and bulrush, must have a bare mudflat as a seedbed," and Harris and Marshall (1963) cited four other papers to the same effect. However, slow regrowth has been observed by R. E. Stewart (oral commun., 1967) wherein perennial species spread slowly outward from shallow water by vegetative propagation. This indicates, at least for the open prairie of the Coteau du Missouri, that continuous flooding may not control the vegetation to the same extent that it does for the areas of the references cited.

In using vegetation as an index of conditions in a pothole, the possibility of areal variations or patterns should be considered. The most obvious one is the variation with permanence extending from the shoreline to deep water. Another pattern observed in several saline potholes occurs where there is spring or seepage inflow of much fresher water. There is then a progression of vegetation of increasing tolerance to salinity in the direction of flow of this fresher water as it mixes w:th the main body of water and becomes more saline.

The depth of water in a pothole and the species of emergent vegetation that may be present or absent represent the total ef:ect of current hydrologic events combined with unusual events of the past. Undoubtedly the effect of the extremely high stages reached by the water in 1950 lasted for a long time. To what extent it governed the order in which potholes went dry in the early 1960's is not known.

\section{REFERENCES}

Eisenlohr, Wm. S., Jr., 1966a, Water loss from a natural pond through transpiration by hydrophytes: Water Resources Research, v. 2, no. 3, p. 443-453.

$1966 \mathrm{~b}$, Determining the water balance of a lake containing vegetation: Internat. Assoc. Sci. Hydrology Pub. 70, Symposium of Garda, 1966, v. 1, p. 91-99.

Harris, S. W., and Marshall, W. H., 1963, Ecology of water-level manipulations on a northern marsh: Ecology, v. 44, no. 2, p. 331-343.

Kadlec, J.A., 1962, Effects of a drawdown on a waterfowl impoundment: Ecology, v. 43, no. 2, p. 267-281.

Kohler, M. A., Nordenson, T. J., and Baker, D. R., 1959, Evaporation maps for the United States: U.S. Weather Bur. Tech. Pafer 37, pls. 2 and 4.

Meyboom, P., 1963, Patterns of groundwater flow in the prairie profile, in Proceodings of hydrology symposium No. 3, ground"vater, November 1962: Natl. Research Council Canada, Subcommittee on hydrology, p. 5--20.

Schrader, T.A., 1955, Waterfowl and the potholes of the North Central States, in Water: U.S. Dept. Agriculture, Yearbook of Agriculture 1955 , p. 596-604.

Shjeflo, J. B., and others, 1962, Current $s$ tudies of the hydrology of prairie potholes: U.S. Geol. Survey Circ. 472, 11 p.

Stewart, R. E., and Kantrud, H. A., 1968, Proposed classification of potholes in the glaciated prairie region, in Small water arsas in the prairie pothole region-Transactions of a seminar: Canadian Wildlife Service Rept. Ser. No. 6, Ottawa, Canada.

U.S. Geographic Board, 1933, Sixth report of the United States Geographic Board, 18901932, p. 238.

U.S. Weather Bureau, 1955, Rainfall intensityduration-frequency curves for selected sta- 
tions in the United States, Alaska, Hawaiian Islands, and Puerto Rico: U.S. Weather Bur. Tech. Paper 25, p. 34.

Willis, W. O., Parkinson, H. L., Carlson, C. W., and Haas, H. J., 1964, Water table changes and soil moisture loss under frozen conditions: Soil Sci., v. 98, no. 4, p. 244-248.
Winters, Harold A., 1967, The extent of the Coteau du Missouri in soutr-central North Dakota, in Glacial geology of the Missouri Coteau and adjacent areas-Midwest Friends of the Pleistocene, Field Conf. 1967 Guidebook: North Dakota Geol. Survey Misc. Ser. 30 , p. $63-70$. 

